\title{
Stock Exchange Maturity And GDP Per Capita
}

Ralph Trecartin (E-mail: rtrecart@brockport.edu), State University of New York - Brockport Mariana Jbantova, State University of New York - Brockport

\begin{abstract}
This study examines the impact of domestic stock exchanges on the economic growth and development of 26 East European and former Soviet Bloc countries. Growth in domestic financial markets should positively influence a country's economic output as measured by GDP per capita. An investigation of the noteworthy relationship between the level of economic activity and both the operations of the current stock market and the existence of stock exchanges prior to communism is formulated. Countries with stock exchanges prior to communism, have reintroduced free-market characteristics more rapidly than those, which did not. A positive correlation between economic activity and variables for volume of stock exchange trade and market value of exchange trade is also found. The number of companies listed and the number of exchange members do not appear to be important variables.
\end{abstract}

\section{Introduction}

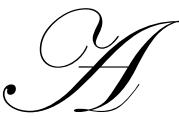

fter the fall of the Berlin Wall in 1989, the disintegration of the Soviet Union, and the fall of communism in Eastern Europe, all of the former communist countries and newly emerging states have faced a variety of economic and financial problems as each one seeks to transition to a market economy. To improve their standard of living and to end their isolation, these countries have embarked on building necessary financial infrastructure and joining various multilateral economic and trade organizations such as the International Monetary Fund, and the World Bank (Lenain 1998). At the same time the international community has responded with investment and logistical support through the European Bank for Reconstruction and Development (EBRD), through foreign direct investment (FDI) by multinational corporations, through syndicated bank financing arrangements, and also through investment from private equity funds (Jury 2000) and (Welfens 2001).

All of these efforts are aimed at overcoming economic problems and developing sustained long-term economic growth. Many of these countries have cherished the eventual goal of entering the European Union and arriving at a developed nation status (Sachs 1996). Early in the market economy transition phase it was believed that achievement of European Union integration would take a sustained period of time. For example, Paul Welfens (2001) estimated that it would take 13 years for a sample of Eastern European countries (Slovenia, Hungary, Poland and the Czech Republic) to catch up with per capita gross domestic product in the countries of the European Union. Eastern European countries would need to achieve average annual growth in GDP of at least $8 \%$ if the EU-15 GDP growth rate were to proceed at $2.5 \%$.

Development of the private sector (N'Diaye 2001), capital markets (Demekas et. al 2002), and regional integration (Sharer 2001) are viewed as driving forces to achieve this economic growth. If the development process follows the pattern of rebuilding in Western Europe after World War II, one should expect gradual convergence in the income gap between East and West (Sachs 1996).

Currently Eastern European and Soviet Block countries can be divided into three groups based on their probable order of acceptance into the European Union. The 10-member enlargement of the EU slated for 2004 includes eight East European countries (see group 1 below). Countries with a stronger financial infrastructure and more mature stock exchanges characterize this group. These countries also have a western geographical location 
making them crucial transportation corridors to the countries located in groups 2 and 3. The countries included in the second group have developed their stock exchanges and other financial infrastructure, but the maturity of these institutions generally lags behind those of countries included in the first group of candidates. The corresponding lag in GDP per capita in group 2 also lags that of countries included in group 1. The characteristics of countries in group 3 reveal generally low levels of stock exchange activity, if any, and low levels of per capita income.

Group 1: $\quad$ Czech Republic, Slovenia, Hungary, Slovakia, Estonia, Poland, Lithuania, and Latvia.

Group 2: $\quad$ Russia, Belarus, Bulgaria, Romania, Croatia, Yugoslavia.

Group 3: Kazakhstan, Georgia, Macedonia, Turkmenistan, Ukraine, Azerbaijan, Armenia, Kyrgyzstan, Moldova, Uzbekistan, Bosnia and Herzegovina, and Tajikistan.

\section{Impediments - Problems Faced During Transition}

Despite a common inheritance from communism and a common desire for sustained economic growth and integration with the West, the 26 East European and former soviet countries demonstrate substantial differences in overcoming impediments to their goals. Some of the impediments include: large levels of external indebtedness (Sachs 1996) and (Lenain 1998), budget deficits (Hunter 1993) and (Sachs 1996), hyperinflation (Sachs 1996), depleted foreign exchange reserves (Lenain 1998), decline in trade after the dissolution of the Council for Mutual Economic Assistance (CMEA) (Lenain 1998), widespread corruption (Sachs 1996), lack of appropriate legal structure (Sachs 1996) and (Jury 2000), and lack of management skills (Jury 2000).

Several of the important problems encountered by these countries, are reflected in the current level and efficiency of their financial infrastructure. The way they approach solving these problems will directly affect their ability to develop well functioning financial markets and to achieve sustained economic growth. In a market based economy the right to private ownership is usually assumed. Moving from a centrally planned economy to one that is market based often results in massive privatization of industry and/or the banking system. Sachs (1996) points to this "structural adjustment crisis" and the downsizing of heavy industry as two of the major issues facing many of these economic regimes.

Of paramount importance to the privatization process are two concerns. The first is the existence of a healthy banking system to bolster and sustain the industrial base. Most East European countries are in the process of overcoming a faulty banking system. The system is often swamped with large levels of bad debt that was originally channeled to inefficient state-run firms. Lack of proper capital allocation processes inevitably result in capital starvation for many of the enterprises that have the greatest potential for success (Hunter 1993) and (Jelic et.al. 1999). The declining level of productivity in the state-run firms has resulted in the reduction of economic growth.

The second concern related to the privatization process is the ability of owners (shareholders) to transfer ownership via the financial markets. Because the markets are "woefully incomplete" (Hunter 1993) and (Sachs 1996), it is hard to attract needed capital for sustained organizational growth and modernization. Jury (2000) states that the lack of a properly functioning stock market is a real deterrent to investment inflows for a country. This problem is alleviated as emerging stock markets become more mature. As Sharer (2001) documents, trade, savings, and investment are tied to a regions macroeconomic framework and financial infrastructure. In the present study the financial infrastructure that a country has accumulated can be used to partially explain the differences in economic growth and the standard of living.

\section{Benefits of Financial Infrastructure - Role of Stock Exchanges}

This study explores the significance of well-functioning stock exchanges and their impact on the improvement process in former communist countries. The role of a stock exchange appears to be vitally important for countries moving toward economic integration with the West. Nsouli and Legall (2001) explain that the mobilization and efficient allocation of savings to productive investments is largely accomplished through a sound 
financial architecture. Several of the most successful transition economies have achieved outstanding increases in the savings rate (Welfens 2001). Stock exchanges are essential to support savings and investment in transition countries.

The current state of many of the country stock exchanges under question is "embryonic" at best (Jelic et. al. 1999). Companies often face solvency problems that the banking system is unable or unwilling to address. With a functioning stock market it becomes easier for these firms to find sources of capital in both domestic and international capital markets (Hausler 2002). A properly functioning stock exchange will not only help companies raise capital, but also help individuals and organizations to diversify their holdings. With thinly traded markets liquidity problems discourage participation by these investors in the financial system. As such, investors will demand higher risk premiums to compensate for lack of liquidity. Thus the company in need of capital is placed at a disadvantage because only relatively more expensive credit is available (Hunter 1993). Solving this problem has helped companies to raise more capital in the most successful transition economies while failure to do so has constrained growth in some of the more backward states.

\section{Stock Exchange Maturity}

The graph in Figure 1 answers the question: Is there a relationship between GDP per capita for a country and the maturity of the country's stock exchange? As can be seen there is a strong positive relationship between these two variables. Income statistics are influenced by a host of factors, but it is clear that maturity rankings capture or proxy for many of these factors.

The maturity ranking is a composite of five significant variables. These variables include: 1) whether there was a stock exchange in operation before 1940 or before the rise of centrally planned economies in the region, 2) how many years have elapsed since the inception of the current stock exchange, 3 ) the number of trades per year on each exchange, 4) the market capitalization of firms listed on each exchange, and 5) the market value of securities traded in U.S \$ terms.

All 26 countries are sorted into three groups for each variable. The variable rankings include, a high maturity score of 3, a medium score of 2 , and a low score of 1 . Countries with the least level of maturity, or non available data on a particular variable are given a score of 1 . The scores for each of these 5 variables are then summed to calculate a composite maturity score. The highest possible score is equal to a rank of 15 (\#3 rank *5 variables), while the lowest possible composite rank is a 5 (\#1 rank * 5 variables). As can be seen in Figure 1, three countries Slovenia, Hungary, and Poland show up on the high end of each of the maturity scale with a rank of 15 while Turkmenistan and Uzbekistan show up on the low end of the scale with a rank of 5.

By maturity one does not only mean the actual functioning of a particular exchange, but also the acceptance and use of mechanisms for transfer of ownership within the society of a country or at least by a portion of that society. For example, it is hypothesized that countries, which housed operational stock exchanges prior to communism are more likely to have embraced a market economy and market based institutions when the opportunity for a capitalistic rebirth became available. This societal acceptance should propel growth in GDP per capita faster than would be expected in countries that do not have strong capitalistic collective memories.

Maturity Rankings are a composite of the five following variables. Each country receives a ranking of 1,2, or 3 on each variable. The variable rankings are then summed providing a composite range from 5 to 15 . A score of 5 indicates low stock exchange maturity while a ranking of 15 is the highest maturity ranking possible. GDP per capita is for 1999 . The R Squared coefficient is $62.5 \%$. 
Variables:

Trade Before 1940:

Years Since Inception:

Number of Trades:

Value of Trades:

MCap\%GDP:
Country given a rank of 3 for the presence of a domestic stock exchange before 1940, or a rank of 1 otherwise.

Countries are ranked according to current stock exchange opening date. Oldest exchanges ranked \#3.

Number of trades or transactions as reported on the stock exchange web-site, ranked. N/A for all countries.

Value of trades in millions of \$US. Source: World Bank Development Indicators Aggregate market capitalization of firms on the exchange as a percent of GDP. Source: World Bank Development Indicators.

The general hypothesis that a mature domestic stock exchange has a strong relationship with GDP per capita is supported. There is a strong, positive, and significant correlation between GDP per capita and many of the stock exchange "maturity" variables examined. Countries that had operational stock exchanges prior to 1940 have a significantly higher standard of living as measured by GDP per capita. The same can be said for stock exchanges that have a larger number of trades, have a larger dollar value of trade, and trade the most units (shares etc.). When the market capitalization variable is scaled by its proportion of the economy (\%of GDP) the variable becomes significant and explains $49 \%$ of the country variation in GDP per capita. The number of listed companies on the exchange, the number of exchange memberships, and the exchange turnover ratio for each country are not significant variables for predicting GDP per capita.

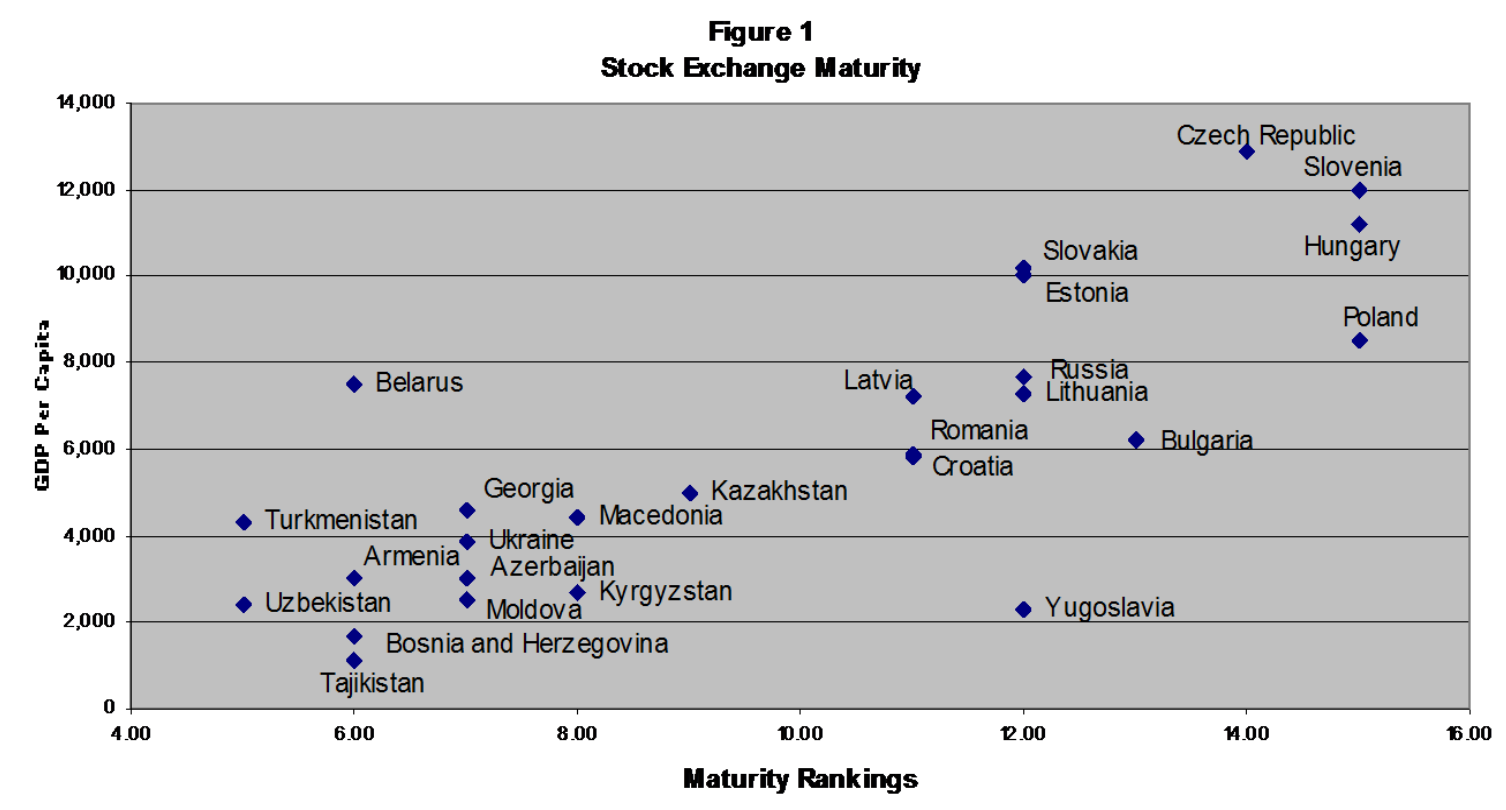

\section{Data}

A portion of the economic and financial data used in this article may be found on the stock exchange web sites shown in Table 1. Stock Exchange Market Capitalization figures are taken from the: Emerging Stock Markets Factbook for 1999, IFC. Any financial data, expressed in a currency other than US Dollars was converted into US Dollars using exchange rates taken during the day the respective piece of information was found on the world-wideweb. Web-site data was collected during October and November of 2001. 
Table 1: Stock exchanges

\begin{tabular}{|c|c|c|c|c|c|}
\hline Country & Stock Exchange Name & Stock Exchange Web Site & $\begin{array}{c}\text { Trade } \\
\text { Before } \\
1940 \\
\end{array}$ & $\begin{array}{l}\text { Start of } \\
\text { Trading }\end{array}$ & $\begin{array}{l}* \text { Value of } \\
\text { Trades in } \\
\text { Bill - US \$ } \\
\end{array}$ \\
\hline Armenia & Yerevan Stock Exchange & N/A & N/A & N/A & 0.100 \\
\hline Azerbaijan & $\begin{array}{l}\text { Baku Interbank Currency } \\
\text { Exchange }\end{array}$ & http://www.az/bicex & N/A & 1994 & N/A \\
\hline Belarus & No & No & N/A & N/A & N/A \\
\hline $\begin{array}{l}\text { Bosnia and } \\
\text { Herzegovina }\end{array}$ & No & No & N/A & N/A & N/A \\
\hline Bulgaria & Sofia Stock Exchange & http://www.bse-sofia.bg & Yes & 1991 & 1.920 \\
\hline Croatia & Zagreb Stock Exchange & http://www.zse.hr & Yes & 1991 & 0.996 \\
\hline Czech Rep. & Prague Stock Exchange & http://www.pse.cz & Yes & 1992 & 103.272 \\
\hline Estonia & Tallinn Stock Exchange & http://www.tse.ee & Yes & 1996 & 7.938 \\
\hline Georgia & Georgian Stock Exchange & http://www.gse.ge & N/A & N/A & N/A \\
\hline Hungary & Budapest Stock Exchange & http://www.bse.hu/ & Yes & 1990 & 338.283 \\
\hline Kazakhstan & Kazakhstan Stock Exch. & http://www.kase.kz & N/A & 1993 & 1.712 \\
\hline Kyrgyzstan & Kyrgyz Stock Exchange & http://www.kse.kg & N/A & 1995 & N/A \\
\hline Latvia & Riga Stock Exchange & http://www.rfb.lv & Yes & 1995 & 1.211 \\
\hline Lithuania & $\begin{array}{l}\text { National Stock Exchange of } \\
\text { Lithuania }\end{array}$ & http://www.nse.lt & N/A & 1993 & 7.128 \\
\hline Macedonia & Macedonian Stock Exch. & http://www.mse.org.mk & No & 1996 & 0.720 \\
\hline Moldova & Moldovan Stock Exchange & http://www.moldse.md & N/A & 1995 & 0.339 \\
\hline Poland & Warsaw Stock exchange & http://www.wse.com.pl & Yes & 1991 & 235.800 \\
\hline Romania & Bucharest Stock Exchange & http://www.bvb.ro/ & N/A & 1995 & 11.925 \\
\hline Russia & $\begin{array}{l}\text { Russian Trading System; } \\
\text { Moscow Stock Exchange }\end{array}$ & $\begin{array}{l}\text { http://www.rts.ru; } \\
\text { http://www.mcse.ru }\end{array}$ & Yes & 1991 & 78.400 \\
\hline Slovakia & Bratislava Stock Exchange & http://www.bsse.sk & N/A & 1991 & 13.272 \\
\hline Slovenia & Ljubljana Stock Exchange & http://www.ljse.si & Yes & 1989 & 8.473 \\
\hline Tajikistan & No & No & N/A & N/A & N/A \\
\hline Turkmenistan & $\begin{array}{l}\text { State Commodity and Raw } \\
\text { Materials Exchange of } \\
\text { Turkmenistan }\end{array}$ & N/A & N/A & N/A & N/A \\
\hline Ukraine & Ukranian Stock Exchange & http://www.ukrse.kiev.ua & N/A & 1992 & 5.682 \\
\hline Uzbekistan & $\begin{array}{l}\text { Toshkent Republican Stock } \\
\text { Exchange }\end{array}$ & N/A & N/A & N/A & 1.200 \\
\hline Yugoslavia & Belgrade Stock Exchange & http://www.belex.co.yu & Yes & 1989 & N/A \\
\hline
\end{tabular}

*Total value of trades in Billions of US \$ is calculated from the "value traded as a \% of GDP" statistics for 1999 as presented in series 5.3 of the Worldbank World Development Indicators found at: www.worldbank.org/data/wdi2001/pdfs/tab5_3pdf.

The financial markets and stock exchanges for the entire 26-country sample are in a state of infancy having been organized or reorganized in the last six to twelve years. Most of the stock markets have been in operation for approximately ten years now, even though some countries had stock exchanges prior to their entry under communist rule. As the governments of these countries gain more experience in regulating the proper functioning of free-market institutions, new laws have been enacted and implemented. The countries with the highest GDP per capita had stock exchanges before 1940. These countries include Slovenia, Poland, the Czech Republic, Hungary, Estonia, Russia and Bulgaria. The rest of the stock exchanges do not report any prior existence or previous operations. Countries with prior stock exchanges also have acquired the highest level of imports and exports and managed to attract the most foreign capital in comparison to the rest of the countries.

The stock exchanges of these countries vary a lot in terms of the number of participants and the number of listed companies. However, these variables have no predictive impact concerning the economic activity of a country. Most of the companies, which are currently traded on the stock exchanges of these former communist countries, are 
privatized state enterprises. The most actively traded of these are assumed by investors to have the greatest potential for success in the new economy. The number of actively traded companies, however, represents only a small fraction of all the companies listed. Therefore, the number of companies listed in an emerging market economy does not translate well into market capitalization or volume of trade for the respective stock exchange.

In almost every former communist country, the number of new private companies, which have gone public, is very short. Foreign and domestic investors are often not willing to deploy resources, thus making it very difficult for those newly founded private companies to attract capital. The lack of a credit history, the lack of trust in market institutions, and the failure by regulatory bodies to insure proper operations by stock exchange players, are all factors that impact stock exchange maturity, and the ability for savings and investment to spur growth in the economy. This makes stock exchange development a necessity but also a daunting challenge.

\section{Conclusions}

Eastern European countries that have progressed the furthest in implementing market economies and building financial infrastructure have on average captured the highest standard of living as measured by GDP per capita. They have also improved their likelihood of successfully being integrated into the European Union sooner rather than later. The establishment and nurture of domestic stock exchanges appears to be one of the important building blocks necessary to spur economic growth. There appears to be a strong relationship between variables that represent stock exchange maturity and GDP per capita.

\section{References}

1. Dimitri Demekas, Johannes Herderschee, James McHugh, and Saumya Mitra, 2002, "Southeastern Europe After the Kosovo Crisis", Finance \& Development, (March), pp. 44-47.

2. $\quad$ Gerd Hausler, 2002, "The Globalization of Finance", Finance \& Development, (March), pp. 10-12.

3. William C. Hunter, 1993, "Banking Reform and the Transition to a Market Economy in Bulgaria: Problems and Prospects", Economic Review, Vol. 78 (1), (January/February), p. 15.

4. International Financial Corporation (IFC). Emerging Stock Markets Factbook for 1999, (April).

5. Ranko Jelic, Richard Briston, and Chris Mallin, 1999, "Gambling Banks and Firm Financing In Transition Economies", Multinational Finance Journal, Vol. 3 (4), (December), pp.253-282.

6. Jennifer Jury, 2000, "Focus: Central and Eastern Europe - Drawing Back the Curtain", European Venture Capital Journal, (March), p. 1.

7. Patrick Lenain, 1998, “Ten Years of Transition: A Progress Report", Finance \& Development, Vol. 35 (3) (September), pp. 22-25.

8. Seyni N'Diaye, 2001, “The Role of Institutional Reforms", Finance \& Development, (December) pp. 18-21.

9. Saleh Nsouli, and Francoise LeGall, 2001, "The New International Financial Architecture and Africa", Finance \& Development, (December), pp.34-36.

10. Jeffrey Sachs, 1996, “The Transition at Mid Decade”, The American Economic Review, Vol. 86 (2), (May), p. 128.

11. Robert Sharer, 2001, "An Agenda for Trade, Investment, and Regional Integration", Finance \& Development, (December), pp. 14-17.

12. Paul J.J. Welfens, 2001, "Stabilizing and Integrating the Balkans: Economic Analysis of the Stability Pact, EU Reforms and International Organizations". Springer, New York, http://www.worldbank.org/html/extdr/regions.htm. 